\title{
Practices of Public Participation in Local Self-Governance: Case Studies of Siberian Villages
}

\author{
M. V. Kondratyev ${ }^{a, *}$ and O. P. Fadeeva ${ }^{a, b, * *}$ \\ ${ }^{a}$ Institute of Economics and Industrial Engineering, Siberian Branch, Russian Academy of Sciences, \\ Novosibirsk, 630090 Russia \\ ${ }^{b}$ Novosibirsk National Research State University, Novosibirsk, 630090 Russia \\ *e-mail: kondratev.post@gmail.com \\ **e-mail:fadeeva@ieie.nsc.ru
}

Received March 1, 2021; revised March 9, 2021; accepted July 16, 2021

\begin{abstract}
Rural local self-governance as an independent political institution in Russia shows clear signs of degradation. Its effectiveness and efficiency have noticeably decreased over time. A reduction in the powers and financial resources of local authorities leads to destructive phenomena and processes: the condition of rural infrastructure is deteriorating, and negative demographic trends are developing. The aim of the study is to assess how the self-organization of rural residents can resist these trends, and to identify and classify the forms of proactive participation of the rural population in local self-governance. Generalization of the sociological research results using the case study method in rural settlements of Novosibirsk Oblast and Krasnoyarsk Krai has made it possible to identify the main types of formal and informal practices of participation of local residents in initiating projects for landscaping, social support, and other local issues. It is concluded that insufficient efficiency on the part of local authorities, their poor provision of resources, and unpreparedness for dialogue with the population entail the emergence of informal types of participation of residents in village life. Informal practices can foster community cohesion and contribute not only to the preservation but also to development of rural settlements. The active involvement of the rural population in various forms of participation makes it possible to partially compensate for the defects of local self-governance and counteract negative trends in the sustenance of rural settlements.
\end{abstract}

Keywords: local self-governance, rural settlements, practices of participation, self-organization, local communities, Siberia, Novosibirsk Oblast, Krasnoyarsk Krai

DOI: $10.1134 / \mathrm{S} 2079970521040079$

\section{FORMULATION OF THE PROBLEM}

The institution of local self-governance in postSoviet Russia dates back to Federal Law no. 131-FZ of October 2003 On the General Principles of Organization of Local Self-Governance in the Russian Federation. ${ }^{1}$ This law describes in detail the legal basis of this institution; the division of spheres of responsibility of federal, regional, and municipal authorities; the structure of territorial entities and local governments; the distribution of powers in resolving issues of local importance between different levels of government; the economic basis for exercising local power (sources of formation local budgets, and self-taxation procedures complementary to them); and the methods and mechanisms for direct participation of the population

\footnotetext{
${ }^{1}$ Federal Law of October 6, 2003 no. 131-FZ (as amended on December 29, 2020) On the General Principles of Organization of Local Self-Governance in the Russian Federation. http://www.consultant.ru/document/cons_doc_LAW_44571/.
}

in administration and other aspects of local self-governance.

Over the almost 20 years since the launch of this institution, significant corrections have been made to its initial design. Thus, the authority of federal subjects in regulating issues of organizing local self-governance was expanded and the procedures for suspending lower municipalities and municipal districts were eased. The number of municipal government powers at the local level was drastically curtailed (from 39 to 13), in combination with redistribution of tax revenues. In addition to a part of tax deductions, the functions of administrating municipal property, and above all, land were transferred upward (from settlements to districts, and in some cases, from urban districts to federal subjects) (Fadeeva, 2019). The legislative changes that have taken place contributed to the "regulated embedding" of local self-governance in the centralized system of state authority (Markvart, 2016). Some authors believe that in the near future, the Russian framework for the formation of a new system of 
public authority with not preserve the autonomy of lower levels of the territorial power structure, even on paper (Blinova, 2019; Platonov, 2020; Pozanenko, 2015).

The redistribution of powers between different levels of government and changes in the structure of budgetary sources allocated to them have contributed to a decrease in independence in the activity of both rural and urban municipalities initially guaranteed by the Constitution of the Russian Federation. In addition, the procedure for the formation of local authority has radically changed. In most cases, direct elections of heads of municipal settlements, municipal districts, and urban districts began to be replaced by competitive procedures through which local deputies and not residents of settlements began to choose, or rather, to appoint, heads of territorial entities (Maikova and Simonova, 2014). In choosing the heads of municipal districts, the wishes of governors and other leaders of federal subjects gained significant weight as they presented their candidates for these positions. As a result, personnel recommendations issued from above began to circumvent the opinions of citizens living in these territories and representatives of local business structures. The merging of territorial entities, the merging of municipal districts into urban districts, and innovations in the "optimization" of local authorities, up to the abolition of the local network of rural municipalities (village councils) began to gain steam. ${ }^{2}$

It is difficult to unequivocally assess the success of the efforts undertaken to increase the efficiency of the power vertical in certain territories. As a rule, this is measured by the cost savings for maintenance of the administrative apparatus, and without taking into account such things as deterioration in the availability of various public benefits for residents of the reorganized territories. The need for such administrative changes and their effectiveness are largely determined by the economic potential of the territories themselves: the success and diversification of local businesses, the volume of financial flows and tax payments generated by them, and the situation on local labor markets. In this sense, the economic and political weakness of the local government and resulting problems of financing the settlement infrastructure derive from the level of economic development of a territory (Kopoteva, 2017).

In rural areas, market reforms have led to major changes (Andreenkov, 2019). Over the past two decades, in Russian, including Siberian, regions, the number of operating agricultural organizations and farms capable of actively participating in the socioeconomic development of villages and performing the functions of reliable taxpayers has decreased several

\footnotetext{
${ }^{2}$ Hurry slowly. The authorities of the Altai krai weighed the pros and cons of dissolving village councils. https://politsib.ru/ news/40911-spesit-medlenno-vlasti-altajskogo-kraa-vzvesili-zai-protiv-likvidacii-selsovetov.
}

times (Dets, 2019; Fadeeva, 2018). The number of jobs has significantly decreased. Lack of work has resulted in increased labor migration of rural residents to large cities and to a shift to natural resource extraction regions. Thus, rural areas have lost a significant number of permanent residents, above all men (Mezhdu domom ..., 2016).

Institutional changes in the local self-governance system, which, following A.A. Auzan (2016, p. 221), can be viewed as "changes distributed in accordance with the developed plan," did not solve the main problems of territorial development. Due to permanent underfunding in many Russian villages, the degradation of life support systems (road network, water and heat supply systems, etc.) is taking place, the availability of medical and educational services is curtailed, opportunities for organizing leisure are reduced, and problems with the collection, storage, and disposal of household waste arise. Hopes for the centralization of funds and powers at the district or a federal subject level have basically not justified themselves: more money was not allocated for the needs of individual settlements, and the redistribution of areas of responsibility dramatically reduced the ability of the administrations of rural settlements to solve pressing problems. Local budgets have become chronic recipients of upper-level budgets (Myslyaeva and Naumenko, 2020). The subsidies (primarily for equalization of budgetary provision depending on the number of registered residents), targeted subsidies and subventions transferred to them, as a rule, provide only a minimum of funds for the remuneration of municipal employees and workers of cultural organizations (the only sphere that has survived in the area of responsibility of rural administrations) and for financing some maintenance work (in rare cases, modernization) of settlements. These interbudgetary relations, in fact, camouflage the fact of the poor capacity of rural municipalities and their actual bankruptcy.

This nature of economic and institutional transformations has intensified the demand on searching for nontraditional mechanisms for preserving of villages and settlements, among which more and more often ways of increasing participation of the population in the development of their territories has begun to be considered, which could at least partially compensate for the failures of local government. The aim of this article is, using the case studies of several territorial entities in rural areas of Novosibirsk Oblast and Krasnoyarsk Krai, to present different practices of participation of the population in local self-governance, the opportunities and limitations associated with them, and the motives and reasons for involving villagers in projects to improve their habitat.

\section{MATERIALS AND METHODS}

A case study was conducted in 2018-2020 in Kuibyshevsky district of Novosibirsk Oblast and Yeniseysky 
district of Krasnoyarsk Krai. The following populated areas were selected for the survey: the village of Abramovo (Novosibirsk Oblast), the village of Verkhnepashino, the settlement of Krivlyak, and the village of Plotbishche (Krasnoyarsk Krai). The choice of populated areas was based on a preliminary analysis of manifestations of civic activity described in the local press. $^{3}$ In rural areas, district newspapers reflect the chronicle of current events that form the local news feed. In the genre of "letters to the editor," there are published pieces on public actions and organized holidays held in different settlements, about the improvement of some street, or about the solution of a particular social problem. The authors of these pieces are amateur journalists from among concerned activists, who thus give a public account to their fellow villagers on fulfilling their social burden. In their materials, they not only reflect facts, but also describe in detail how everything came about: who proposed what idea, how they managed to realize it, what funds were involved, what they managed and failed to do.

The residents of the surveyed populated areas were interviewed about the motives and methods of their participation in various electoral campaigns, in initiative projects for improving territories of settlements, and in other local events. A total of 20 interviews were conducted, including with leaders of public organizations and representatives of local authorities.

The surveyed populated areas are quite different from each other. Two of them - the villages of Abramovo and Verkhnepashino-are large: in 2019, 1306 people were registered in Abramovo, and 2340 in Verkhnepashino. These villages are located $8-9 \mathrm{~km}$ from the district centers, which provides residents with access to a wider variety of jobs. Two other populated areas are the forest settlement of Krivlyak and the village of Plotbishche, which have about 800 and 300 inhabitants respectively); however, Krivlyak is a remote (the distance to the regional center is more than $300 \mathrm{~km}$ ) and hard-to-reach territory. The settlement can be reached only by plane or along the Yenisey River during the navigable period.

A special economic situation has developed in each of the settlements. In Abramovo, a large agricultural enterprise with a wide profile operated until 2018, when it was liquidated due to bankruptcy. At the time of the survey, the local labor market was represented by a small number of farms, trade enterprises, services, and budgetary organizations. Unlike Abramovo in Novosibirsk Oblast, work in the settlements of Krasnoyarsk Krai is mainly related to logging, gathering wild plants, fishing, and, to a lesser extent, agriculture. Also, for residents of the villages of the Krasnoyarsk

\footnotetext{
${ }^{3}$ The objects of analysis were publications in official print media: in the newspapers Trudovaya Zhizn (Kuibyshevsky district) and Yeniseyskaya Pravda (distributed in the city of Yeniseysk and Yeniseysky district). Both newspapers have electronic and print versions.
}

Krai, rotational shift work has gained in popularity the northern regions-in gold mines and oil and gas production sites. The largest employer in our sampling is a timber processing plant of the Siblesproekt holding in Verkhnepashino. Despite the fact that it has provided jobs for more than 200 local residents, a significant part of tax deductions resulting from its activity did not pass to the local budget, but was sent to the place of registration of the parent organization. Nevertheless, thanks to the sponsorship of this large enterprise, the local administration managed to implement several social projects, and the village art school was refurbished. In Krivlyak and Plotbishche, there is essentially no organized economic activity. In addition to traditional public sector organizations (school, club, etc.), there were separate private sawmills; the local population was actively engaged in semilegal timber harvesting and transport.

The budgetary provision per one registered resident in all four settlements over the course of three years varied from RUB 5000 to 9000 . The increase in revenues to rural budgets in some years was caused not by an increase in the tax base or other economic processes, but by the inclusion of the settlement in some regional programs related to the repair of roads, the development of the center of settlements and the resettlement of residents from dilapidated housing. In other years, the expenditures of local budgets were mainly directed to the item "National issues," from which the activity of local administrations were financed, and the item "Culture," to pay employees of clubs, music schools, and other facilities remaining on the balance sheets of municipalities. Over a three-year period, the item "Social Protection" in rural budgets has practically been zeroed out in connection with the transfer of corresponding powers from municipalities to regional ministries of social policy or development, as well as other items related to the operation of housing and communal services.

The budgets of two small rural settlements (Krivlyak and Plotbishche) were 95-96\% subsidized. Thus, it was as though the budgets of other levels of government were supporting these settlements at their own expense. But interbudgetary relations successfully mask the fact that the active development of the significant forest and other natural resources of these territories in no way affects the possibilities and conditions of their development. Natural rent from large-scale logging and export of Siberian timber and other local resources goes to completely different budgets and hardly reaches the rural level at all.

\section{RESULTS}

Analysis of the survey materials allows us to highlight the substantive elements of various practices of participation of the population in local self-governance and classify its main types: representative and 
project participation and situational and problem-oriented self-organization.

Representative participation involves delegation of powers and rights assigned to the population related to solving issues of local importance, as well as to the official local self-governance bodies (rural administrations and councils of deputies) through participation in electoral procedures. In this case, the practice of self-governance is transformed into the practice of subject-object administration. For the public, this is the most common and easiest way to participate. The electoral activity and level of support for elected heads of administrations and deputies among rural residents are traditionally high, but this does not prevent voters from actively criticizing the "servants of the people" for inactivity or even suspecting them of corruption: We had such a head of administration here, over whom a trial seems to be still pending. He traded in land and took the computer home from the administration. He started building a cottage for himself, then this was covered up, because he broke ranks in a major way (Novosibirsk Oblast).

The population tries to elect deputies of village councils without regard to their party affiliation, but on the basis of ideas about the good that they could bring to the village. A similar pragmatic approach is also followed by employees of rural administrations involved in election campaigns. Recently, they have tended to propose as deputies not candidates who are ready to vote for the adoption of the next budget or other decisions without any discussion, or who have a lot of free time (we are talking about pensioners), but those who have their own businesses, are financially well provided, and therefore can help with solving some particular important rural problem.

Previously, here, they voted for communists, then for other parties. So, they elected such deputies, who began to quickly relieve themselves of their powers. Among them there were many pensioners who either got tired of this work, or they refused because of illness. And we, as the administration, had to organize these elections again. However, this was expensive: you need to pay for the work of the election commission and print various materials. Now we are trying to somehow convey to the public consciousness that it is necessary to support candidates who can really help the village: drive a dump truck for repairs or select a grader to clear roads (Novosibirsk Oblast).

Disappointment among villagers for the people they elect is observed quite frequently. Moreover, already at the campaigning stage, voters are well aware of the positive and negative qualities of candidates, but they still hope for a miracle and buy into pre-election promises. However, the loss of confidence in a particular deputy or head of administration does not negate the belief of villagers in the importance of electoral procedures. They consider it their duty to attend citizen meetings and public hearings, where heads of set- tlements and deputies report on their activity or consult with them.

Other examples of representative participation of the population include various cases of filing petitions to higher authorities with requests for aid in solving urgent problems or with complaints about "administrative inaction" of village heads. In interviews, the respondents more than once noted their "deep dissatisfaction" with what was happening around them, but they themselves did not strive to do anything to correct the situation. At any opportunity, it was easier for them to express their concern about what was happening, to "shift the blame" to the authorities (after all, they are responsible for solving problems) and underscore their own powerlessness.

Our roads are not in the best condition. My son has a car, and he is constantly indignant at the shape the roads are in as soon as spring or autumn comes. We complain to the district: at best, a grader will be sent when it gets really bad (Novosibirsk Oblast).

Our problem is that the district lives its own life. I know the workers of the district administration: they will do no more than they are now. We are not satisfied with their work, but we cannot influence it (Krasnoyarsk Krai).

Unlike representative participation, project participation implies more active involvement of the rural population and entrepreneurs in solving local problems. In recent years, this has been happening thanks to new organizational forms that are gaining popularity, such as proactive budgeting (Vagin and Shapovalova, 2016) or grant support. This method of participation, on the one hand, presupposes a high degree of self-organization of the rural community and cofinancing of expenses, and on the other hand, it is projected from above, through specially adopted programs at the regional level. Depending on the scenario for the implementation of projects, which, as a rule, relate to improvement of rural areas, the participants are assigned roles. Local residents create initiative groups, on behalf of which they build interaction with the authorities, collect funds, seek opportunities to provide additional assistance, e.g., from business, in supporting projects: ${ }^{4}$ If we want to do something in the village, we only hope for competition. The head always helps us in this: the administration helped to prepare the documents for participation in the program "Yenisey Coast." We also had a lot of work to do: first, hold meet-

\footnotetext{
${ }^{4}$ An example of such programs is the competition of projects of local initiatives "Yenisey Coast." It is being carried out under the state program of Krasnoyarsk Krai "Assistance in Developing Local Self-Governance." The competition involves the creation of an initiative group from among the residents of the municipality, which must, together with the local administration, develop and implement a project for the development of infrastructure, improvement of the settlement. The program provides for the participation of citizens in financing the project, which must be at least $3 \%$ of the total cost. In other programs, the share of citizens' cofinancing can reach up to $30 \%$ or more.
} 
ings in organizations, then organize a village meeting. If in general public opinion is for us, then we conduct a survey to determine the idea, look for a sponsor, and attach questionnaires and photos. The more information is submitted to the competition, the easier it will be to win there (Krasnoyarsk Krai).

The population, which is not actively involved in the project work, selects one of the proposed options for the arrangement of settlements: among the proposals may be the construction of a children's playground or sports pitch, repair of a section of road, or the reconstruction of a lighting system. At meetings, residents discuss the procedure and standards for self-taxation of each household and other forms of participation, e.g., community cleanup days: At the meeting, the participants discussed and then established streetlights in the village. A little money was collected from the population, only RUB 50 per person. The total amount of contributions from residents was RUB 30 000. Now the streets are brightly lit (Krasnoyarsk Krai).

Initiative group participants are engaged in the planning and preparation of tender documentation, monitoring the observance of publicity in adopting general decisions and achieving consensus. The participation of the population in such projects is limited by the formal requirements and timing of the project, which is additional complexity for its initiators and requires special expertise. At the same time, within the project, goals, objectives are clearly formulated, and the final result and the amount of necessary funds are determined. The responsibility of the executors is also detailed. This contributes to achievement of the planned results.

The residents of the rural settlements we interviewed cited different motives for their participation in initiative budgeting projects, but they all in one way or another boiled down to the fact that a common good created by joint efforts (e.g., lighting a village) will certainly affect the well-being of each household and increase the level of safety in the village. In parallel with these assessments, doubts were voiced about the fairness of shifting financing to people for services that should be paid for out of the local or regional budget. At the same time, the respondents admitted that in the current situation, it is unlikely that it will be possible to improve living conditions in rural areas in any other way: local budgets do not have the necessary funds; therefore, it is necessary to participate in various competitions to obtain additional funds and then in cofinancing initiative projects: The three hundred rubles that our family donated for lighting is not money for us. The fact that it the streets are now lit is great: children used to return from school when it was pitch dark. But the very principle that in addition to taxes we still need to replenish some funds is incomprehensible. But who will do this if not us?! (Krasnoyarsk Krai).

The situational self-organization of villagers in local self-governance is possible under the threat of certain emergencies: fires, floods, and other natural disasters, for which, perhaps, neither local authorities nor residents themselves are fully prepared. As an example of a spontaneous initiative in one of the villages we surveyed, we can cite the organization of a temporary fire and rescue squad during the spring grass fires, which led to numerous blazes and threatened houses and summer cottages in the settlement. Residents of the rural settlement organized shifts and actively helped to eliminate hot spots. In fighting fires, the institution of street elders, established relatively recently, also acquitted itself well. The elders took it upon themselves to inform the population and identify violations.

Threats of fires in villages arise quite regularly, but as a rule there are no specialized fire brigades in the field. At best, the administration may have a fire engine at its disposal, most often not very maneuverable and not designed to extinguish fires in large areas. Therefore, in interviews, people spoke out for residents to be more responsible in fighting fire, snot to set fire to the grass, to monitor the situation and to have equipment designed to extinguish fires in their backyards. The respondents were very upset by the carelessness of both fellow villagers and townspeople vacationing in the countryside: With the burning of the grass, history repeats itself every year. People think that ticks will be poisoned like that-someone just sets a fire.

There is one "bukhanka" with a ladder for three villages; it's not yet clear where they will station it. We are not entitled to forest conservation: it is not a forest that is on fire. By the time the truck reaches us, the fire may have spread to houses. We try to keep an eye out and signal if we suddenly see a fire. It is good that people still have tractors. Everybody has barrels; we were asked to start keeping them (Novosibirsk Oblast).

The spontaneous and informal nature of this type of participation is due to a difficultly identifiable intragroup system of administration, coordination, and control. Each of the participants in spontaneous actions is responsible only for fulfillment of his task, often offered to him, based on a self-assessment of his own capabilities and resources. People are driven by concern for the well-being of loved ones and fate of their property. Success to a large extent depends on the degree of solidarity of the population in solving a common problem or preventing a common threat. In some cases, when the rural community is unable to influence overcoming an emergency (announced or not), the form of manifestation of situational self-organization can be picketing, rallies, or other gatherings of citizens, organized without observation of established procedures or legal decision-making.

\footnotetext{
5 "Bukhanka" or "uazik" are popular names for utility vehicles from various modifications of all-terrain vehicles (serial production began in 1958). For more details see: https://www.uazbusiness.ru/cars/classic/passenger/uaz-buhanka-anniversary. Aaccessed July 23, 2021.
} 
Problem-oriented self-organization of rural residents occurs in response to the ineffectiveness of existing government institutions for resolving problem situations within the borders of settlements. This kind of self-organization requires active and influential informal leaders. Leaders organize intragroup communication, develop plans for the implementing emerging initiatives, and look for sponsors. Local communities can also rely on their cultural, religious, and other local traditions. The specifics of rural life contribute to the formation of various informal groups consisting of people united by life together in the same territory, i.e., friendly, neighborly, and family relationships. For active residents of rural settlements, the concepts of "patriotism" and "civic responsibility" are not empty words. Residents are used to getting together often to discuss the current agenda, in cooperation with representatives of the official authorities, to find ways to celebrate the Day of the Village or organize a historical and recreational zone: As a rule, those who work do not have time to participate in such events. But in the club, we have a full hall gathered, we vote, and take decisions. The village council consults with us, and the head of administration is present at all meetings (Krasnoyarsk Krai).

Another layer of intravillage self-organization concerns the provision of targeted assistance to elderly residents and families in difficult life situations. In one of the villages included in our sampling, there is a volunteer team ready to respond to certain "local challenges," including those associated with the sudden outbreak of the COVID-19 pandemic: Now, after the announcement of quarantine, we are bringing food home to all our old ladies. There was only one social worker left in our village; the others were "optimized." We help everyone who needs it, otherwise neither the social worker not the school counselor worker will be able to cope with this (Krasnoyarsk Krai).

Modern means of communication are used as information channels for self-organization in Siberian villages: messaging apps and social networks. The older population prefers to transmit information "by word of mouth" to broadcast requests for help, which, in their opinion, is more reliable: On WhatsApp, people sometimes write that they need help-you can immediately ask how to help. There is also a group on Odnoklassniki, but there it's mostly advertising: someone is selling a poultry or a refrigerator. My grandmother knows all the news about what's happening where, who needs what, when she goes to the store or to the post office (Krasnoyarsk Krai).

Thus, the streamlined functions of power can be partially compensated by self-initiative. People are well aware of which of their fellow villagers is at risk but does not have support from the state, and they are ready to come to the rescue without orders from above.
Table 1 presents a generalized description of the typology of formal and informal self-governance practices developed by us. The identified types of participation of villagers in local self-governance can be combined with each other depending on the local specifics: the socioeconomic situation in a particular settlement, the established relations between the authorities and the population, the presence of different interest groups. The level of socioeconomic development of the surveyed rural settlements is to a certain extent determined by the state of the administration system and its transformations. The degradation of the settlement infrastructure and the consequences of a wide variety of "optimizations" that we recorded in Novosibirsk Oblast and Krasnoyarsk Krai can also be observed in villages and towns in other regions. However, in our opinion, there are significantly fewer opportunities and resources for development in the peripheral remote territories of Siberia. It is not without reason that our respondents noted only two of the advantages of the rural lifestyle: the nature and fresh air offered by Siberia, while other characteristics of place of residence-the availability of work, condition of roads, availability of basic services (medicine, housing and communal services, culture, sports and recreation, including the conditions for classes with children) - as a rule, were rated rather low.

As noted above, the most active leaders of the administrations of rural settlements and local activists are trying to improve local living conditions by participating in competitions for projects of initiative budgeting, which come down from the top. Although not always ready-made design solutions can cover the entire range of rural problems, any opportunity to attract additional resources is important for the preservation of settlements. Residents of rural settlements rarely refuse to participate in all sorts of hearings, elections of projects and self-taxation procedures to implement albeit modest (especially by urban standards) measures to improve living space. As a rule, we are talking about the partial modernization of the street lighting system (literally on the same street) or the creation of the only children's playground or sports pitch in the village.

\section{CONCLUSIONS}

The generalization of the survey results made it possible to construct a classification of the practices of participation of the rural population in local self-governance. Part of the range of formalized practices we attributed to the type of representative participation, in which residents fully delegate their rights to the official authorities. Another relatively new format is project (competitive) participation, which implies that rural activists, in cooperation with the local administration, obtain the rights to implement a development project using funds from regional and local budgets, as well as donations from the population and business. 
Table 1. Typology of practices of participation of rural population in local self-governance

\begin{tabular}{|c|c|c|}
\hline Type of participation & Practice of participation & $\begin{array}{l}\text { Motive/reason for involving the population in } \\
\text { participatory practices }\end{array}$ \\
\hline \multicolumn{3}{|c|}{ Formal participation } \\
\hline $\begin{array}{l}\text { Representative partici- } \\
\text { pation }\end{array}$ & $\begin{array}{l}\text { Participation in local elections. } \\
\text { Appeals (complaints) to local authorities. } \\
\text { Participation in reporting events and hearings. }\end{array}$ & $\begin{array}{l}\text { Political position and the availability of its manifes- } \\
\text { tation. } \\
\text { Dissatisfaction with quality of work of local authori- } \\
\text { ties. } \\
\text { Skills and traditions of participation in electoral } \\
\text { campaigns. }\end{array}$ \\
\hline $\begin{array}{l}\text { Project participation } \\
\text { (preparation of projects } \\
\text { for competition and } \\
\text { organization of cofi- } \\
\text { nancing) }\end{array}$ & $\begin{array}{l}\text { Initiation of project. } \\
\text { Project implementation. } \\
\text { Project financing (self-taxation, attraction of } \\
\text { sponsorship from business structures). }\end{array}$ & $\begin{array}{l}\text { Lack of necessary funds from official authorities. } \\
\text { Availability of regional support programs for imple- } \\
\text { mentation of expensive rural projects. } \\
\text { Interest of residents and business structures in } \\
\text { developing social, engineering, and technical infra- } \\
\text { structure of village. }\end{array}$ \\
\hline \multicolumn{3}{|c|}{ Informal participation } \\
\hline $\begin{array}{l}\text { Situational self-organi- } \\
\text { zation }\end{array}$ & $\begin{array}{l}\text { Strong resistance to emergencies. } \\
\text { Elimination of consequences of natural disas- } \\
\text { ters. }\end{array}$ & $\begin{array}{l}\text { Situational omission of authorized persons. } \\
\text { Remoteness (absence) of equipment and engineer- } \\
\text { ing infrastructure facilities. } \\
\text { Direct threat to safety of life of population, housing, } \\
\text { and business zones of settlements. }\end{array}$ \\
\hline $\begin{array}{l}\text { Problem-oriented self- } \\
\text { organization }\end{array}$ & $\begin{array}{l}\text { Helping fellow villagers in difficult life situa- } \\
\text { tions. } \\
\text { Self-directed implementation of socially ori- } \\
\text { ented initiatives. } \\
\text { Independent implementation of initiatives to } \\
\text { develop infrastructure of settlement. }\end{array}$ & $\begin{array}{l}\text { Lack of necessary funds and authority on part of } \\
\text { official authorities. } \\
\text { Civil position of representatives of initiative group. } \\
\text { Skills and traditions of self-organization of local } \\
\text { communities. }\end{array}$ \\
\hline
\end{tabular}

We consider the informal participation of the population within the framework of situational and problemoriented self-organization.

People of retirement age play a peculiar role in local self-governance. They initiate projects for the improvement and development of territories and lead the movement for their implementation. It should be noted, however, that young residents far from always agree with the initiatives of their elders to transform the environment. They may be rejected by the projects and structures of informal interaction proposed by older activists. For this reason, the human capital of rural youth may remain unclaimed, and the needs of young residents of rural settlements may not be met.

A trend that has intensified in the past few years for more active involvement of citizens in decision-making related to the development of the "small homeland" (place of residence) ${ }^{6}$ should be supplemented by

\footnotetext{
${ }^{6}$ In accordance to the provisions of Federal Law of July 20, 2020 no. 236-FZ On Amendments to the Federal Law On General Principles of Organization of Local Self-Governance in the Russian Federation, from January 1, 2021, the Law on People's Budgeting was launched in Russia (http://www.consultant.ru/law/hotdocs/63662.html/).
}

the return to local authorities the real powers. In conditions when the solution of key life support issues has been transferred to district and regional authorities (whether it is the authority to manage land, arrange the territory, or care for it, including transfer of responsibility for waste disposal to a single operator), one should not expect that the decrease in the activity of the municipal authorities will be compensated by the practices of self-organization of the rural population. In specific conditions of survival or in the creation of communities of an ecological or religious nature, people in their daily life may well do without the participation of the state. However, under normal conditions, it is at least short-sighted to remove the official authorities further and further from the population under the slogan of streamlining and centralization. At the same time, as our research has shown, there is no need to abolish the already established potential of civic engagement and viable local practices. It is important to think about how to further stimulate and design self-organization mechanisms in order to take into account the interests of different groups, prevent acute conflicts, and provide an oppor- 
tunity for consensus in the interaction of government, business, and the population.

\section{FUNDING}

The article was prepared according to the plan of research of Institute of Economics and Industrial Engineering, Siberian Branch, Russian Academy of Sciences (project no. 121040100280-1, "Actors, Drivers, Consequences of Social Changes in Modern Society: Theory and Empiricism”).

\section{CONFLICT OF INTEREST}

The authors declare no conflict of interest.

\section{REFERENCES}

Andreenkov, S.N., Reforms of the system of farms and land use in the 1990s in Novosibirsk oblast, Krest'yanovedenie, 2019, vol. 4, no. 4, pp. 58-75.

Auzan, A.A., Institutsional'naya ekonomika: Novaya institutsional'naya ekonomicheskaya teoriya (Institutional Economics: New Institutional Economic Theory), Moscow: Prospekt, 2016.

Blinova, N.V., Inflation of a local government, PolitBook, 2019 , no. 2 , pp. 63-83.

Dets, I.A., Agroindustrial complex of Siberia as a resource of territorial development, Uch. Zap. Krymsk. Fed. Univ. im. I. Vernadskogo, Geogr., Geol., 2019, no. 3, pp. 38-53.

Fadeeva, O.P., Agrarian policy in the reflection of Russian agricultural censuses, EKO, 2018, no. 12, pp. 143-162.
Fadeeva, O.P., Siberian village: from formal self-government to forced self-organization, $E K O, 2019$, no. 4, pp. 71-94.

Kopoteva, I.V., Theoretical approaches to the study of the reforms of local self-government in Russia, Krest'yanovedenie, 2017, vol. 2, no. 4, pp. 31-55.

Maikova, E.Yu. and Simonova, E.V., The electoral mechanism in the formation of local self-government bodies in modern Russia, Vlast', 2014, no. 11, pp. 105-109.

Markvart, E.E., Russian local self-government and the general challenges of present time, Ross. Ekon. Zh., 2016, no. 6, pp. 3-17.

Mezhdu domom i ... domom. Vozvratnaya prostranstvennaya mobil'nost' naseleniya Rossii (Between Home and ... Home. The Return Spatial Mobility of Population in Russia), Nefedova, T.G., Averkieva, K.V., and Makhrova, A.G., Eds., Moscow: Novyi Khronograf, 2016.

Myslyaeva, I.N. and Naumenko, T.V., Specific financial mechanisms of local self-government in Russia, $Z h$. Issled. Sots. Polit., 2020, no. 1, pp. 69-82.

Platonov, V.M., The principle of the unity of executive power in the federal structure of modern Russia, Vestn. Ross. Univ. Druzhby Nar., Ser.: Sotsiol., 2020, vol. 20, no. 1 , pp. $145-160$.

Pozanenko, A.A., Consequences of the enlargement of rural settlements, Vopr. Gos. Munits. Upr., 2015, no. 1, pp. 168-184.

Vagin, V.V. and Shapovalova, N.A., Proactive budgeting and related practices, Fin. Anal.: Probl. Resheniya, 2016, no. 38 , pp. 2-19. 